\title{
The Relationship between Inflammatory Markers and Mean Platelet Volume in Patients with Diabetic Foot Infection
}

\author{
Diyabetik Ayak İnfeksiyonu ile İzlenen Hastalarda İnflamatuar Belirteçler ile MPV illişkisinin Değerlendirilmesi
}

Cigdem Ozkan, Isilay Kalan, Ozlem Turhan Iyidir, Ethem Turgay Cerit, Mujde Akturk, Alev Altinova, Fusun Balos Toruner Metin Arslan

Gazi University Faculty of Medicine Division of Endocrinology and Metabolism, Ankara, Turkey

\section{ABSTRACT}

Objective: Diabetic foot infections (DFI) is one of the most common and debilitating complications of diabetes. Mean platelet volume (MPV), which is reported routinely in complete blood count has been shown to be increased in patients with diabetes. Higher MPV values have also been shown to be related with increased risk of cardiovascular events and thrombosis. In this study we aimed to study MPV values in DFI during the acute stage and after treatment, and its relationship between inflammatory markers.

Patients and Methods: Data of all diabetic patients with DFI followed up in the Endocrinology and Metabolism Unit of Gazi University Hospital between 2004-2012 were reviewed. Forty-seven patients with diabetic foot osteomyelitis were included into the study. Erythrocyte sedimentation rate (ESR), C-reactive protein (CRP), white blood cell (WBC) count, platelet count, and MPV levels were recorded at baseline and after treatment from the computerized patient registry database.

Results: The mean age of the patients included in the study was $59.4 \pm 10.0$ years. Thirty-one $(66 \%)$ patients were male. Median duration of diabetes was 15 (3-30) years. Median HbA1c was 7.9\% (5.2-14). ESR, CRP, WBC and platelet counts were significantly decreased after treatment when compared to the baseline $(p<0.05)$. Following the treatment, we found an increase in MPV values from $8.58 \pm 1.38$ to $8.68 \pm 1.74$ (fl), but this was not statistically significant ( $p>0.05$ ). MPV did not correlate with ESR, CRP and WBC counts before and after treatment in diabetic foot osteomyelitis.

Conclusion: The results of our study suggest that values of MPV might not be used as a marker in DFI. Prospective studies with larger number of patients are needed to evaluate the role of MPV in diabetic foot infections.

Key Words: Diabetic foot infection, inflammatory markers, mean platelet volume

Received: 03.24.2016
Accepted: 04.11.2016
ÖZET

Amaç: Diyabetik ayak infeksiyonu (DAi), diabetes mellitus ile izlenen hastalarda en sık karşılaşılan, ciddi ve maliyeti yüksek komplikasyonlarından biridir. Tam kan sayımında rutin olarak rapor edilen ortalama trombosit hacminin (MPV) diyabetik hastalarda arttığı rapor edilmiştir. Ayrıca yüksek MPV değerlerinin artmış kardiyovasküler risk ve tromboz ile ilişkili olduğu belirtilmiştir. Bu çalışmada diyabetik ayak osteomyeliti olan hastalarda akut dönemde ve tedavi sonrasında MPV değerlerinin inflamatuar belirteçler ile ilişkisini belirlemeyi amaçladık.

Gereç ve Yöntem: Çalışmamızda 2004-2012 yılları arasında Gazi Üniversitesi Endokrinoloji ve Metabolizma Hastalıkları Kliniğinde izlenen ve kayıtlarına ulaşılabilen diyabetik ayak osteomyeliti ile izlenmiş olan kırk-yedi hastanın tedavi öncesinde ve sonrasında eritrosit sedimentasyon hızı (ESR), C- reaktif protein (CRP) değerleri, beyaz küre sayısı, trombosit sayısı ve MPV değerleri retrospektif olarak değerlendirildi.

Bulgular: Hastaların ortalama yaşı $59.4 \pm 10.0$ yıl olarak tespit edildi. Otuz-bir hasta (\%66) erkekti. Ortanca DM süresi 15 yıl ( 3-30), ortanca glikolize hemoglobin (HbA1c) değeri \%7.9 (\%5.2- 14) olarak bulundu. Tedavi sonrasında ESR, CRP değerlerinde, beyaz küre sayısı, trombosit sayısında istatiksel olarak anlamlı düşüş tespit edildi $(p<0.001, p<0.001, p<0.001, p=$ 0.01 ). Tedavi sonrasında MPV değerlerinde $8.58 \pm 1.38 \mathrm{fl}$ 'dan $8.68 \pm 1.74 \mathrm{fl}$ 'a artış izlendi ancak bu artış istatistiksel olarak anlamlı bulunmadı $(p=0.60)$. MPV değeri ile tedavi öncesinde ve sonrasında ESR, CRP değerleri ve beyaz küre sayısı arasında bir korelasyon tespit edilmedi.

Sonuç: Çalışmamı sonuçları MPV değerlerinin DAi izleminde bir belirteç olarak kullanılmasını desteklememektedir. Ancak MPV değerlerinin DAi izleminde rolünün belirlenmesi için daha geniş sayıda hasta ile yapılacak prospektif çalışmalara intiyaç vardır.

Anahtar Sözcükler: Diyabetik ayak infeksiyonu, inflamatuar belirteçler, ortalama trombosit hacmi

Geliş Tarihi: 24.03.2016

Kabul Tarihi: 11.04.2016 


\section{INTRODUCTION}

Diabetic foot infections (DFI) are one of the most common, severe and costly complications of diabetes (1). DFI, including osteomyelitis, are the leading cause of hospital admission and lower extremity amputations in patients with diabetes (2-3). In general; osteomyelitis requires antibiotic therapy and according to clinical presentation, treatment might necessitate surgical debridement (3). The determination and resolution of DFI is important for successful DFI treatment. Inflammatory markers like erythrocyte sedimentation rate (ESR), C-reactive protein (CRP), and procalcitonin (PCT) were evaluated in previous studies and ESR was suggested to be the best laboratory test for diagnosing and monitoring treatment of DFI (4-6).

Mean platelet volume (MPV) is one of the platelet indices and reported routinely in complete blood count ( $C B C$ ). It is used as an indicator of size distribution of platelets and related with platelet production and activation (7). In previous studies, platelet activation, production of larger thrombocytes and enlargement of circulating platelets in diabetes have been reported (8-10). Higher MPV values have also been shown to be related with increased risk of cardiovascular events and thrombosis (11-12). On the other hand, it has been reported that MPV may decrease in high grade inflammatory disorders (13-14). To the best of our knowledge, there is no study in the literature investigating MPV values and its relation with other inflammatory markers in DFI. In this study, we aimed to study MPV values in diabetic foot osteomyelitis during the acute stage and again after treatment, and its relationship between inflammatory markers.

\section{MATERIALS and METHODS}

This retrospective cohort study was performed at the Department of Endocrinology and Metabolism of Gazi University, Ankara, Turkey. The study was approved by the Gazi University ethics committee. Electronic hospital data systems and medical charts of patients were reviewed. All patients who had been followed up with DFI between 2004-2012 were identified. Fortyseven patients with diabetic foot osteomyelitis were enrolled in the study. Patients with diagnoses of platelet disorders that led to thrombocytopenia or thrombocytosis and patients with high-grade inflammatory disorders other than osteomyelitis were excluded from the study. ESR, CRP, white blood cell (WBC) count, platelet count, and MPV values measured at baseline and after treatment were recorded from electronic hospital data systems.

\section{Statistical Analysis}

Statistical analysis was performed via Statistical Package for Social Sciences (SPSS) for Windows, Version 21.0 software (IBM). Normality of the distribution was investigated with Shapiro-Wilks test. Numeric variables are presented as mean \pm standard deviation or median (interquartile range) values. Categorical variables are presented as counts and percentages. Chisquare test was performed to evaluate the differences between the groups. The comparisons of the values before and after treatment were performed with dependent group $t$-test. Pearson or Spearman correlation coefficient was used to detect the associations between numeric variables. $p$ value $<0.05$ was considered statistically significant.

\section{RESULTS}

The mean age of the patients was $59.4 \pm 10.0$ years. Thirty-one $(66 \%)$ of the patients were male. The median duration of diabetes was 15 years (3-30 years). All patients were under insulin therapy. Median glycated hemoglobin (HbA1c) was 7.9\% (5.2-14\%). Thirty-seven patients (79\%) were treated with antibiotics, 10 patients (21\%) were treated with antibiotics and surgical treatment. Treatment of osteomyelitis was continued according to IDSA guidelines (15) and with resolution of osteomyelitis WBC count, platelet count, ESR, CRP and MPV values were reevaluated. WBC counts, platelet counts, ESR and CRP values were significantly decreased after treatment when compared to baseline [WBC count $\left(x 10^{3} / \mu \mathrm{L}\right) 10.2 \pm 5.3$ vs. $8.0 \pm 3.0$, $\mathrm{p}<0.001$; platelet count $\left(x 10^{3} / \mu \mathrm{L}\right) 313.5 \pm 141.0$ vs. $263.4 \pm 71.1, \mathrm{p}=0.01 ; \mathrm{ESR}$ $77.3 \pm 34.1$ vs. $42.4 \pm 26.5(\mathrm{~mm} / \mathrm{hr}), \mathrm{p}<0.001$; CRP 24.0 vs. $3.6(\mathrm{mg} / \mathrm{dl})$, $\mathrm{p}<0.001)$. Following the treatment, we found an increase in MPV values from $8.58 \pm 1.38 \mathrm{fl}$ to $8.68 \pm 1.74 \mathrm{fl}$, but this was not statistically significant $(p=0.60)$. Demographic features and clinical parameters of patients before and after treatment are shown in Table 1. MPV did not correlate with ESR, CRP and WBC counts before ( $p=0.90, p=0.27, p=0.07$; respectively) and after $(p=0.92, p=0.75, p=0.54$; respectively) treatment in osteomyelitis.

Table 1. Demographic features and clinical parameters of patients before and after treatment

\begin{tabular}{|c|c|c|c|c|}
\hline & & Before Treatment $(n=47)$ & After Treatment ( $n=47)$ & $p$ value \\
\hline Age (years) & $59.4 \pm 10$ & & & \\
\hline Gender (male, \%) & $31(66 \%)$ & & & \\
\hline Duration of DM (years) & $15(3-30)$ & & & \\
\hline $\mathrm{HbA1C}(\%)$ & $7.9(5.2-14)$ & & & \\
\hline WBC $\left(x 10^{3} / \mu \mathrm{L}\right)$ & & $10.2 \pm 5.3$ & $8.0 \pm 3.0$ & $<0.001$ \\
\hline $\operatorname{PLT}\left(x 10^{3} / \mu \mathrm{L}\right)$ & & $313.5 \pm 141.0$ & $263.4 \pm 71.1$ & 0.01 \\
\hline $\mathrm{ESR}(\mathrm{mm} / \mathrm{hr})$ & & $77.3 \pm 34.1$ & $42.4 \pm 26.5$ & $<0.001$ \\
\hline $\mathrm{CRP}(\mathrm{mg} / \mathrm{dl})$ & & $24(1-329)$ & $3.00(1-33)$ & $<0.001$ \\
\hline MPV (fl) & & $8.5 \pm 1.3$ & $8.68 \pm 1.7$ & 0.50 \\
\hline
\end{tabular}

WBC: White blood cell count, PLT: Platelet count, ESR: Erythrocyte sedimentation rate, CRP: C-reactive protein, MPV: Mean platelet volume.

\section{DISCUSSION}

Our study showed that there is no significant change in MPV values after osteomyelitis treatment in diabetes, and no significant relation between inflammatory markers and MPV values during treatment of osteomyelitis.

$\mathrm{DFI}$ is one of the most frequent complications of diabetes and it is the major cause of hospitalization among diabetic patients (16-17). TURDEP-II study revealed that the prevalence of diabetes in Turkey is $13.7 \%$ and compared to TURDEP-1, the rate of increase in diabetes was $90 \%$. (18-19). Recently, a study from Turkey showed that $28 \%$ of patients with DFI required amputations and $34 \%$ of these were major amputations (20). In the light of these data, diagnosis and monitorization of treatment of DFI is very important to avoid amputations and to achieve successful treatment of DFI.

Several studies investigated inflammatory markers in the diagnosis and monitorization of treatment in DFI. Recently, Asten et al. reported that procalcitonin might be useful in the diagnosis of osteomyelitis and CRP, ESR, interleukin- 6 and procalcitonin in monitoring the treatment (21). Michail et al. also investigated CRP, WBC count, ESR, PCT in the diagnosis and follow-up of diabetic patients with osteomyelitis, and among these, ESR was recommended for monitorization during follow up (4). In these studies, all the parameters decreased effective treatment. The findings of our study were also consistent with the findings of those studies. ESR, CRP and WBC counts in our study significantly decreased post-treatment.

Platelets mainly play a role in hemostatis, but recently, studies have shown that platelets also contribute to inflammation and MPV, which is a parameter of platelet activation, might be used as a marker for inflammation $(13,22-23)$. Diabetic state, which is also considered as low-grade inflammation, leads to an increase in MPV values $(10,24-26)$. Demirtunç et al. reported a positive correlation between $\mathrm{HbA} 1 \mathrm{c}$ values and MPV in diabetic patients. In the same study, improved glycemic control resulted in decreased MPV values (27). Large and activated platelets may contribute to vascular complications of diabetes (28-29). 
Contrary to low-grade inflammation, studies showed that MPV values decrease in high-grade inflammatory disorders such as active rheumatoid arthritis, ankylosing spondylitis and inflammatory bowel disease (13-14). The results of our study did not reveal any significant change in MPV values or any relationship with other inflammatory markers. Our patients had diabetes, which contributes to changes in MPV values and also osteomyelitis, which leads to high-grade inflammation. The presence of both might lead to changes in MPV values, but which one contributes more is currently unknown. In a study investigating the benefits of hyperbaric oxygen therapy in patients with diabetic foot, MPV values decreased significantly after treatment (30). The results of our study are not consistent with this study. Since our patient group had osteomyelitis, treatment strategies differed between the two groups, which could explain the inconsistency of the results. As far as we are aware, this is the first study in the literature investigating MPV values and its relationship with other inflammatory markers in DFI.

There are limitations of our study that need to be mentioned. First of all, this is a retrospective study. Secondly, we did not evaluate the effect of complications such as renal failure or cardiovascular complications on MPV values. Inclusion of a limited number of patients was another limitation of this study.

\section{CONCLUSION}

The results of our study suggest that MPV levels do not significantly change in the treatment period of osteomyelitis, and also that MPV is not related with other inflammatory parameters. Thus, MPV might not be used as a marker in DFI. The results of our study suggest that serum CRP, ESR and WBC significantly decrease after treatment. Therefore, these markers might be used during treatment monitorization. However; since MPV is a component of routine the blood count test and an inexpensive parameter, prospective studies with larger number of patients are needed to evaluate the role of MPV in DFI.

\section{Conflict of interest}

No conflict of interest was declared by the authors

\section{REFERENCES}

1. Richard JL, Lavigne JP, Sotto A. Diabetes and foot infection: more than double trouble. Diabetes Metab Res Rev 2012;28 Suppl 1:46-53.

2. Lipsky BA, Peters EJ, Senneville E, et al. Expert opinion on the management of infections in the diabetic foot. Diabetes Metab Res Rev 2012;28 Suppl 1:163-78.

3. Nyazee HA, Finney KM, Sarikonda M, et al. Diabetic foot osteomyelitis: bone markers and treatment outcomes. Diabetes Res Clin Pract 2012;97:4117.

4. Michail M, Jude $E$, Liaskos $C$, et al. The performance of serum inflammatory markers for the diagnosis and follow-up of patients with osteomyelitis. The international journal of lower extremity wounds 2013;12:94-9.

5. Fleischer AE, Didyk AA, Woods JB, Burns SE, Wrobel JS, Armstrong DG. Combined clinical and laboratory testing improves diagnostic accuracy for osteomyelitis in the diabetic foot. The Journal of foot and ankle surgery : official publication of the American College of Foot and Ankle Surgeons 2009;48:39-46.

6. Jeandrot A, Richard JL, Combescure C, et al. Serum procalcitonin and Creactive protein concentrations to distinguish mildly infected from noninfected diabetic foot ulcers: a pilot study. Diabetologia 2008;51:347-52.

7. Park $Y$, Schoene $N$, Harris $W$. Mean platelet volume as an indicator of platelet activation: methodological issues. Platelets 2002;13:301-6.

8. Inui $Y$, Suehiro $T$, Kumon $Y$, Hashimoto $K$. Platelet volume and urinary prostanoid metabolites in non-insulin-dependent diabetes mellitus. J Atheroscler Thromb 1994;1:108-12.
9. Zuberi BF, Akhtar N, Afsar S. Comparison of mean platelet volume in patients with diabetes mellitus, impaired fasting glucose and non-diabetic subjects. Singapore Med J 2008;49:114-6.

10. Hekimsoy Z, Payzin B, Ornek T, Kandogan G. Mean platelet volume in Type 2 diabetic patients. J Diabetes Complications 2004;18:173-6.

11. Leader A, Pereg D, Lishner M. Are platelet volume indices of clinical use? A multidisciplinary review. Annals of medicine 2012;44:805-16.

12.Slavka, G., Perkmann, T., Haslacher, H., Greisenegger, S., Marsik, C.,

Wagner, O.F.al. Mean platelet volume may represent a predictive parameter for overall vascular mortality and ischemic heart disease. Arteriosclerosis, thrombosis, and vascular biology 2011; 31: 1215-8.

13. Kisacik B, Tufan A, Kalyoncu U, et al. Mean platelet volume (MPV) as an inflammatory marker in ankylosing spondylitis and rheumatoid arthritis. Joint, bone, spine : revue du rhumatisme 2008;75:291-4.

14. Kapsoritakis AN, Koukourakis MI, Sfiridaki A, et al. Mean platelet volume: a useful marker of inflammatory bowel disease activity. Am J Gastroenterol 2001;96:776-81.

15. Lipsky BA, Berendt AR, Cornia PB, et al. 2012 Infectious Diseases Society of America clinical practice guideline for the diagnosis and treatment of diabetic foot infections. Clinical infectious diseases : an official publication of the Infectious Diseases Society of America 2012;54:e132-73.

16. Winkley K, Stahl D, Chalder T, Edmonds ME, Ismail K. Quality of life in people with their first diabetic foot ulcer: a prospective cohort study. Journal of the American Podiatric Medical Association 2009;99:406-14.

17. Uckay I, Aragon-Sanchez J, Lew D, Lipsky BA. Diabetic foot infections: what have we learned in the last 30 years? International journal of infectious diseases : IJID : official publication of the International Society for Infectious Diseases 2015;40:81-91.

18. Satman I, Yilmaz T, Sengul A, et al. Population-based study of diabetes and risk characteristics in Turkey: results of the turkish diabetes epidemiology study (TURDEP). Diabetes Care 2002;25:1551-6.

19. Satman I, Omer B, Tutuncu $Y$, et al. Twelve-year trends in the prevalence and risk factors of diabetes and prediabetes in Turkish adults. European journal of epidemiology 2013;28:169-80.

20. Saltoglu N, Yemisen M, Ergonul O, et al. Predictors for limb loss among patient with diabetic foot infections: an observational retrospective multicentric study in Turkey. Clinical microbiology and infection : the official publication of the European Society of Clinical Microbiology and Infectious Diseases 2015;21:659-64.

21. Van Asten SA, Nichols A, La Fontaine J, Bhavan K, Peters EJ, Lavery LA. The value of inflammatory markers to diagnose and monitor diabetic foot osteomyelitis. International wound journal 2015.

22. Yuksel $O$, Helvaci $K$, Basar $O$, et al. An overlooked indicator of disease activity in ulcerative colitis: mean platelet volume. Platelets 2009;20:277-81. 23. Endler G, Klimesch A, Sunder-Plassmann H, et al. Mean platelet volume is an independent risk factor for myocardial infarction but not for coronary artery disease. Br J Haematol 2002;117:399-404.

24. Sharpe PC, Trinick T. Mean platelet volume in diabetes mellitus. The Quarterly journal of medicine 1993;86:739-42.

25. Papanas N, Symeonidis G, Maltezos E, et al. Mean platelet volume in patients with type 2 diabetes mellitus. Platelets 2004;15:475-8.

26. Domingueti $C P$, Dusse LM, Carvalho MD, de Sousa LP, Gomes KB, Fernandes AP. Diabetes mellitus: The linkage between oxidative stress, inflammation, hypercoagulability and vascular complications. J Diabetes Complications 2015.

27. Demirtunc R, Duman D, Basar M, Bilgi M, Teomete M, Garip T. The relationship between glycemic control and platelet activity in type 2 diabetes mellitus. J Diabetes Complications 2009;23:89-94.

28. Tschoepe $D$, Roesen $P$, Esser $J$, et al. Large platelets circulate in an activated state in diabetes mellitus. Seminars in thrombosis and hemostasis 1991;17:433-8.

29. Iwase $E$, Tawata M, Aida $K$, et al. A cross-sectional evaluation of spontaneous platelet aggregation in relation to complications in patients with type II diabetes mellitus. Metabolism 1998;47:699-705.

30. Karadurmus N, Sahin M, Tasci $C$, et al. Potential benefits of hyperbaric oxygen therapy on atherosclerosis and glycaemic control in patients with diabetic foot. Endokrynologia Polska 2010;61:275-9. 